\title{
DOA SEBAGAI KOMUNIKASI TRANSEDENTAL DALAM PRESPEKTIF KOMUNIKASI ISLAM
}

\author{
Umar Abdur Rahim \\ Jurusan Ilmu Komunikasi Faklutas Dakwah dan Komunikasi \\ Universitas Islam Negeri Sultan Syarif Kasim Riau \\ Email:Umarabdur@uin-Suska.ac.id
}

\begin{abstract}
Abstrak
Kajian ini fokus pada kajian hakikat doa sebagai sebuah sarana komunikasi transedental antara manusia dengan Tuhannya, yaitu seorang muslim dengan Allah Swt. Argumennya adalah bahwa di samping sebuah ibadah yang memiliki syariat berupa tata cara yang telah diberikan tuntunannya, doa juga sesungguhnya memiliki esensi komunikasi. Yaitu komunikasi antara manusia dengan Tuhannya yang justru sangat berperan penting pada sampainya pesan dan terkabulnya atau diijabahnyadoa yang dipanjatkan.Pendekatan dalam kajian ini menggunakan kajian kepustakaan, dengan mempelajari dan mengumpulkan data dari literature, buku-buku serta sumber yang relevan dan mendukung.Hasil menunjukkan bahwa hakikat doa dalam ajaran dan prespektif komunikasi Islam, sesungguhnya bukanlah hanya sekedar ritual keagaaman saja, akan tetapi doa juga sesungguhnya memiliki esensi sebagai sarana komunikasi. Yaitu komunikasi antara manusia dengan Tuhannya yang justru sangat berperan penting pada sampainya pesan dan terkabulnya sebuah doa.
\end{abstract}

Kata Kunci :Doa, Komunikasi Transedental, danKomunikasi Prespektif Islam 


\section{Pendahuluan}

Doa adalah suatu aktifitas yang sangat dekat dalam kehidupan manusia. Ia menjadi bagian yang tidak dapat dilepaskan dalam tapak tilas sejarah kehidupan religius manusia. Melalui doa manusia mencurahkan segala harapannya kepada Tuhan yang merupakan suatu Dzat yang dianggapnya berada diluar batas kemampuannya, ${ }^{1}$ dan dijadikannya sebagai tempat berlindung dan meminta.

Dalam ajaran Islam, doa adalah sebuah aktifitas yang dilakukan dalam rangka menyeru, memohon bantuan dan pertolongan kepada Allah Swt. ${ }^{2}$ Bahkan dalam definisi lain doa bukan hanya diartikan sebagai permintaan, permohonan, dan pertolongan kepada Allah Swt saja, namun doa juga adalah merupakan bagian dari ibadah $^{3}$ yang ada dalam ajaran Islam. Dalam Islam doa dilakukan dalam rangka perwujudan rasa syukur dan penghambaan diri kepada Allah Swt supaya terhindar dari mara bahaya dan mendapatkan manfaat dari rasa syukur dan rasa cinta yang diberikan yaitu berupa keridhoan Allah $\mathrm{Swt}^{4}$

\footnotetext{
${ }^{1}$ Komarudin Hidayat Dan Muhmmad Wahyuni Nafis, Agama Masa Depan: Persepektif Filsafat Pernial, Jakarta, Paramadina, 1995) h. 35

2. Abû Hafash Umar bin „Ali bin Adil al-Dimsyq al-Hambali, alLubâb fî̀ „Ulûm al-Kitâb, juz II, cet. I (Beirut: Dâr al„Ilmiyah, 1998), h. 297

3.Abd al-Qadir Ahmad Atha, Hadzâ Halâl wa Harâm, (Beirut: Dar al-Kutub alIlmiyah, 1405 H/1985 M), h. 100

4. M. Majmae al-Lugah al-,,Arabiyah, Mu jam Alfầz al-Qureeân al-Karîm (Kairo:

Dâr al-Syurûq, t.th.), h. 204.
}

kepada diri manusia sebagai makhluk ciptaan-Nya.

Zakiyah Darajat memaparkan bahwa doa merupakan suatu dorongan moral yang mampu melakukan kinerja terhadap segala sesuatu yang berada diluar eksistensi dan jangkauan teknologi. Kata doa dapat diartikan sebagai kegiatan yang menggunakan kata-kata, baik yang dilakukan secara terbuka, bersamasama atau secara pribadi untuk mengajukan segala harapan dan keinginan kepada Tuhan. ${ }^{5}$

Rudolf Otto coba memberikan indikasi terhadap orang yang berdoa atau beragama, dalam dua terminologinya yaitu pertama; tremendum yang mencerminkan rasa atau perasaan orang yang mendatangi Tuhannya dengan suasana takut, dan kedua; facsinans yang mencerminkan perasaan seseorang yang mendatangi Tuhannya dikarenakan adanya rasa ketertarikan dan juga harapan yang diinginkannya. $^{6}$

Dalam hal ini, sepertinya apa yang terminologikan oleh Rudolf Otto tentang doa, bahwa dalam doa sedikitnya mempunyai dua indikasi yaitu pertama; tremendum yang mencerminkan perasaan orang yang mendatangi Tuhan dengan suasana takut, dan kedua; facsinans yang mencerminkan perasaan ketertarikan dan harapan, sejalan dengan apa yang di ajarkan Al-qur ${ }^{\text {ee }}$ an. Al-qurean memberikan tuntunan kepadaseorang muslim bahwa dalam berdoa kepada

\footnotetext{
${ }^{5}$ RobertH.Thouless,PengantarPsikolo giDoa,Cet.Ketiga,(Jakarta:RajaGrafindoPers ada,2000),hal.16

${ }^{6}$.Rudolf Otto, The Idea of the holy,London, Oxpord University Press, 1923, h. 12
} 
Allah Swt hendaknyaharuslah diikuti dengan perasaan takut dan penuh harapan serta keoptimisankepadaNya ( Al-A"eraaf ayat:56). ${ }^{7}$

Di sisi yang lain, selain memberikan panduan dalam tata cara berdoa, secara hakikat Al-qur"an juga memberikan penekanan dan penjelasan bahwa doa sesungguhnya bukanlah hanya sebuah aktifitas ibadah yang dilakukan sekadar mencerminkan perasaan seseorang yang mendatangi Tuhannya dengan rasa takut dan penuh harapan saja, akan tetapi dalam doa haruslah juga diikuti dengan menghadirkan segenap hati (khusyuk) yang dipenuhi dengan getaran cinta yang menghidupkan dan menerangi jiwa(QS. Al-Anbiya:90). ${ }^{8}$

Bahkan dalam kajian yang lebih mendalam dijelaskan bahwa, sesungguhnya doa bukanlah hanya sekedar kegiatan atau ceremonial ibadah yang dilakukan seorang hambahanya ketika menginginkan, memohon atau meminta sesuatu kepada Allah Swt saja, namun lebih dari itu sesungguhnya doa memiliki esensi kedekatan yang lebih dalam, yaitu adanya hubungan dialektis dalam dimensi vertikal antara manusia dengan Tuhannya(QS. AlBaqarah:186). ${ }^{9}$

Nurcholis

Majid menyebutkan bahwa do"a dalam artian seruan kepada Allah Swtsesungguhnya merupakan titik sentral daripertumbuhan kesadaran

7. Kementerian Agama RI, Hijaz The Practice, Bandung, Syaamil Qurean,2013. h.311

8 . Ibid,h. 655

9 . Ibid,h.53 ketuhanan $^{10}$ yang ada dalam diri manusia.Esensi dan substansi dari doaini adalah adanya komunikasi antara manusia dengan Tuhannya yang dibangun secara sadar oleh manusia. Yaitu komunikasi yang melibatkan manusia dengan Tuhannya inilah yang sering disebut komunikasi transendental. ${ }^{11}$

Tulisan ini mencoba mencermati doa sebagai sebuah sarana komunikasi transendental yang terjadi antara manusia dengan Tuhannya dalam tinjauan prespektif komunikasi Islam. Adapun yang dimaksud dengan doa di sini adalah sebuah aktifitas yang biasa dilakukan dalam kehidupan dan ibadah seorang muslim dalam rangka meminta dan memohon sesuatu kepada Tuhannya yaitu Allah Swt.

Penekanan pada tulisan ini adalah pada hakikat bahwa berdoa sesungguhnya adalah sebuah sarana komunikasi transedental antara manusia dengan Tuhannya, yaitu seorang muslim dengan Allah Swt. Argumennya adalah bahwa di samping sebuah ibadah yang memiliki syariat berupa tata cara yang telah diberikan tuntunannya, doa juga sesungguhnya memiliki esensi komunikasi. Yaitu komunikasi antara manusia dengan Tuhannya yang justru sangat berperan penting pada sampainya pesan dan terkabulnya atau diijabahnyadoa yang dipanjatkan.

\footnotetext{
10. Nurcholis Majid, Islam Agama

Peradaban Membangun Makna dan Relevansinya Doktrin Islam dalam Sejarah, (Cet. I; Jakarta: Paramdina, 1995), h.200.

11. Deddy Mulyana, Nuansa-Nuansa Komunikasi; Meneropong Politik Dan

Budaya Komunikasi Masyarakat Kontemporer (Remaja Rosdakarya, Bandung: 1999) h. 49
} 


\section{Metodologi}

Jenis penelitian ini berbentuk penelitian kepustakaan (Library Research).Penelitian kepustakaan ialah penelitian yang dilaksanakan dengan menggunakan dan mengumpulkan literatur (kepustakaan), baik berupa buku, catatan, maupun laporan hasil penelitian terdahulu ${ }^{12}$.Sedangkan untuk analisis data, penelitian ini menggunakan analisis deskriptif yaitu suatu metode dengan jalan mengumpulkan data, menyusun atau mengklasifikasi, menganalisis dan menginterpretasikannya ${ }^{13}$.

\section{Pembahasan}

\section{Doa Sebagai Inti Ibadah}

Kebahagiaan adalah sesuatu yang ada dalam benak dan keinginan setiap manusia, apa pun latar belakang budaya dan agamanya, semuanya mempunyai keinginan yang sama yaitu meraih kebahagiaan dalam kehidupannya, baik dalam kehidupannya didunia maupun dalam kehidupannya akhirat yang lebih kekal dan abadi.

Dalam diri manusia terdapat sebuah naluri dasar yang sangat melekat dan menjadi bagian dan menjadi ciri dari manusia, naluri dasar tersebutlah yang membuat manusia memiliki kemampuan survive dan mampu menhadapi apapundalam kehidupan yang dijalaninya. Naluri itu pula yang menjadikan manusia memiliki hasrat dan ambisi untuk memiliki sesuatu

\footnotetext{
${ }^{12}$.IqbaI Hasan, Analisis Data Penelitian Dengan Statistik,JakartaBumi Aksara, 2008), hal. 5.

${ }^{13}$.Muhammad Natsir, Metode Penelitian, ( Jakarta : Ghalia Indonesia, 1999) hal. 64
}

yang berharga dan berarti dalam hidupnya.

Naluri dasar tersebut adalah adanya dorongan dalam diri manusia naluri untuk selalu mencari nikmat dan menghindari segala bentuk bahaya atau kesengsaraan. ${ }^{14}$ Secara sederhana, dorongan dalam diri manusia sebenarnya hanya memiliki dua hal yaitu mencari nikmat dan menghindari sengsara. Jika ada kenikmatan maka manusia akan mengejarnya, dan jika ada kesengsaraan maka baik secara sengaja ataupun tidak, manusia akan menghindarinya. Hal ini juga didukung oleh aliran behaviorisme yang memandang bahwa dasar perilaku manusia juga didasari oleh dua prinsip reinforcement yaitu adanya reward dan punishment. Prinsip ini menjelaskan, bahwa dasar manusia melakukan sesuatu dipengaruhi oleh adanya rangsangan menghindari hukuman atau siksaan dan mengharapkan hadiah atau pahala. ${ }^{15}$

Karena konsep dasar perilaku manusia ini pulalah yang menjadi penyebab mengapa manusia mencari Tuhannya dan beragama.Agama dalam kehidupan manusia adalah sesuatu yang secara faktual dan tidak dapat dipisahkan dari aktifitas kehidupan manusia.Agama merupakan sesuatu yang secara kodrati sudah ada, menjadi fitrah, kebutuhan dan menyatu dalam diri manusia. ${ }^{16}$ Fitrah menurut Quraish

\footnotetext{
14. Djamaluddin Ancok Dan Fuad nashori Suruso, Psikologi Islam : Solusi Islam Atasi Problem-Problem Psikologi, Yogyakarta, Pustaka Pelajar, 1994.h.71 ${ }^{15}$. Ibid.h.74

16 .H. Ramayulis.Psikologi Agama, Jakarta: kalam Mulia, 2002 h. 26
} 
Shihab memiliki ciri berupa kecenderungan manusia untuk menyenangi sesuatu yang benar, baik dan indah. ${ }^{17}$ Sehingga hadirnya agama menjadi sebuah wadah untuk memberikan ketenangan batin dan jiwa, ${ }^{18}$ menghindari sengsara dan mendapatkan nikmat. Oleh sebab ini pula manusia menceburkan dirinya dalam agama danberbagai macam ritual keagamaan, yang salah satunya adalah doa.

Doa adalah salah satu ritual yang ada dalam setiap agama. Dalam Islam, doa dengan berbagai bentuk penyebutannya disebut sebanyak 213 kali yang terdapat didalam 55 surat dalam Al-qurean. Dalam ayat-ayat tersebut, kata doa dapat berarti undangan, seruan ${ }^{19}$, atau panggilan ${ }^{20}$, dan juga dapat bermakna ibadah ${ }^{21}$, memohon bantuan dan pertolongan, permintaan $^{22}$ atau percakapan, memanggil, atau memuji ${ }^{23}$ dan lain sebagainya. Quraish Shihab menjelaskan doa sebagai permintaan yang ditujukan oleh seseorang kepada siapa yang dinilai oleh si peminta mempunyai kedudukan dan kemampuan yang melebihi

\footnotetext{
17 .M. Quraish Shihab,Tafsir AlAmanah, Pustaka Kartini, 1994.h.374

18. Rusmin Tumanggor, Ilmu Jiwa Agama,Jakarta, Prenadamedia group,2014.h.42

19. Ahmad Warson Munawir, AlMunawir: Kamus Arab-Indonesia (Surabaya: Pustaka Progresif, 2002), h. 402.

20 . Departemen Agama RI, Syaamil Qurean The Miracle, Bandung, Sygma Examedia,2009.h.559
${ }^{21}$. Ibid.h.437
22 . Ibid.h.
${ }^{23}$ Ibid.h.415

kedudukan dan kemampuan dirinya.$$
\text { Toshihiko menjelaskan }
$$

bahwa doa adalah segala usaha yang dilakukan manusia untuk melakukan hubungan verbal dengan Tuhannya dan berusaha melakukan komunikasi dengan-Nya melalui isyarat bahasa, ${ }^{25}$ dan symbol-simbol bahasa lainnya.Melalui doa pula manusia dapat membangun sebuah hubungan yang berada diluar dimensinya sehingga dapat terhubung dengan Tuhannya.

Menurut Thoshihiko, timbulnya keinginan dalam diri manusia untuk berkomunikasi dengan Tuhan disebabkan adanya masalah kehidupan atau kesengsaraan yang dihadapinya. Masalah kehidupannya tersebut biasanya berada di luar batas diri dan kemampuannya sebagai manusia biasa $^{26}$.Al-quran menginformasikan bahwa sudah menjadi bagian dari sifat manusia bahwa ketika ditimpa masalah, manusia berdoa pada Tuhannya untuk menghilangkan kesulitan dan meminta petunjuk serta jalan keluar atau solusi untuk menghadapi masalah tersebut. ${ }^{27}$

Dalam berdoa pada Tuhan, biasanya ada keinginan dan harapan yang dimiliki manusia agar doa yang dipanjatkan didengar dan mendapat respon dari Tuhan. Respon tersebut dapat berupa terjawabnya pertanyaan yang ditanyakannya kepada Tuhan

${ }^{24}$. M. Quraish Shihab, Wawasan alQurean tentang Zikir dan Doa, cet. ke-3 (Jakarta: Lentera Hati, 2008), h. 178.

${ }^{25}$.Toshihiko, Relasi Tuhan, hal. 213.

26 . Toshihiko Izutsu, Relasi Tuhan dan Manusia, terj. Agus Fakhri Husain, dkk (Yogyakarta: Tiara Wacana, 1997), hal. 213.

27 . Departemen Agama RI, Syaamil Qurean The Miracle.h.655 
atau terwujud dan terkabulnya keinginan yang dimintanya kepada Tuhan. Dalam ajaran Islam, diresponnya doa tersebut dikenal dengan istilah diijabahnya sebuah doa. $^{28}$

Doa dalam ajaran Islam adalah sesuatu yang sangat penting. Iamenjadi bagian dari perintah Allah dan sunnah Nabi yang harus ditaati dan dijadikan bagian dari kehidupansehari-hari bagi seorang muslim yang mengaku beriman kepada Allah Swt dan RasulNya. Bahkan dalam sebuah hadist Rasulullah menjelaskan bahwa doa adalah inti dari semua ibadah (HR. Tirmidzi: 3247). ${ }^{29}$ Pentingnya doa ini juga dapat dilihat dari beberapa ayat Al-qur ${ }^{\text {ecan }}$ yang menggambarkan adanya perintah dari Allah Swt kepada manusia terutama kepada hamba-hambaNya yang beriman untuk berdoa, memohon dan meminta kepadanya. Perintah ini dapat dilihat dalam Surat Al-Mukmin ayat 60 yang berbunyi :

"Dan Tuhanmu berfirman: "Berdoalah kepada-Ku, niscaya akan Kuperkenankan bagimu. Sesungguhnya orang-orang yang menyombongkan diri dari menyembah-Ku akan masuk neraka Jahannam dalam keadaan hina dina". (QS. Al-Mu'min: 60).

Dalam ayat yang lain juga dilihat pada surat Allah berfirman :

${ }^{28}$. Toshihiko, Relasi Tuhan, hal. 216.

29 . At-Tirmiż̀̄, Jāmie at-Tirmiżī "Kitāb ad-Da"eawāt: Bāb Mā Jāee a fĩ Faḍl adDu "eā" (Riyāḍ: Bait al-Afkār ad-Daulyah, T.th), hal. 534, hadīis no. 3371

\begin{abstract}
"Dan apabila hambahamba-Ku bertanya kepadamu tentang Aku, maka (jawablah), bahwasanya Aku adalah dekat.Aku mengabulkan permohonan orang yang berdoa apabila ia memohon kepada-Ku, maka hendaklah mereka itu memenuhi (segala perintah-Ku) dan hendaklah mereka beriman kepada-Ku, agar mereka selalu berada dalam kebenaran"(QS. Al-Baqarah: 186).
\end{abstract}

Ayat ini menjelaskan bahwa Allah Swt memberikan perintahNya kepada manusia yang merupakan makhluk ciptaanNya untuk meminta dan memohon kepadaNya, dengan berkata "Berdoalah kepada-Ku, niscaya akan Kuperkenankan bagimu". Dalam ayat ini pula Allah Swt sekaligus memberikan ancaman yang keras kepada manusia yang menyombongkan diri dan tidak mau meminta kepada Allah Swt dengan ancaman akan dimasukkan kedalam neraka dalam keadaan yang hina dina.

Dari ayat ini secara tekstual dan kontekstual, dapat dilihat bahwa doa mempunyai arti yang sangat penting. Penting karena pertama, dapat dilihat bahwa dalam perintah ini Allah Swt membuka diriNya dengan rendah hati kepada manusia atau siapa saja untuk dapat berhubungan dan terhubung serta dekat denganNya yang dapat 
dilakukan manusia melalui cara berdoa kepadaNya. ${ }^{30}$

Kedua, melalui ayat ini Allah Swt membuka diriNya sebaga pencipta kepada ciptaanNya yaitu manusia untuk meminta apa saja dari diriNya, sehingga manusia tidak hanya datang atau dekat karena takut denganNya, akan tetapi juga datang karena memiliki harapan dan mengakui kehambaan diri dihadapanNya. ${ }^{31}$ Ketiga, melalui ayat ini pula Allah Swt memberikan gambaran jelas tentang diriNya bahwasanya Dialah Sang yang Maha Pencipta yang layak untuk dimintai oleh manusia, tempat manusia mengabdikan diri serta sebagai tempat meminta dan memohon(QS.Al-Fatiha: 1-7). ${ }^{32}$

Terakhir, Melalui ayat ini Allah Swt mempertegas keberadaan DiriNya sebagai Tuhan yang layak Disembah, sekaligus memperkenalkan DiriNya dan berbicara mengenai Ke-EsaaNya sebagai Tuhan yang menciptakan manusia, memberikan kehidupan, memberikan rezeki, karunia dan lain sebagainya. Melalui ayat ini pula Allah Swt memberikan ganjaran dan juga ancaman berupa neraka yang hina dina bagi siapa saja yang menyombongkan diri dalam arti kepada manusia yang tidak mau menyembahNya, dan tidak mau memohon atau enggan mentaati perintahNya(QS. Al-Gafir: 60). ${ }^{33}$

\footnotetext{
${ }^{30}$. Muhammad Abdul Qadir Alcaff, Doa Puncak Penyesalan \& Tobat (Jakarta: Zahra, 2008), h. 14

31 . Departemen Agama RI, Syaamil Qur'ean The Miracle,h.869

32 . Ibid.h.1
33 . Ibid,h.945
}

Perintah berdoa ini, apabila ditinjau dari kacamata hukum fiqih maka doa adalah sesuatu yang sudah mendekati pada sebuah kewajiban bagi seorang muslim yang mengaku beriman dan taat kepadaNya. Perintah doa dalam Al-qurean juga diiringi contoh-contoh dengan menceritakan kisah-kisah manusia atau umat terdahulu yang berdoa kepada Allah Swt. Sehingga dari sini dapat dilihat bahwa Allah Swt menggambarkan secara jelas bahwa doa adalah suatu amalan yang sangat penting bagi kehidupan manusia.

Begitu urgennya doa dalam ajaran Islam sehingga dapat pula dilihat bahwa doa juga adalah sebuah amalan yang dilakukan oleh manusia-manusia pilihan Allah Swt yaitu para Nabi dan para Rasul. Bahkan dalam Al-qurean juga dapat dijumpai bahwa hampir setiap Nabi dan Rasul mempunyai amalan doanya masing-masing yang dijabarkan pada beberapa surat dalam Al-qurean.

Memahami hakikat do"e adalah puncak dari semua urusan agama. Dalam sebuah hadist Nabi Muhammad Saw Menjelaskan bahwa

"Tidak ada sesuatu pun yang lebih mulia di sisi Allah dari pada do'a." (HR. Tirmidzi :3370).

Oleh karena itulah Ajaran Islam disebut juga dengan agama doa, karena hampir dalam setiap amalan dan keseharian dalam kehidupan yang dilalui seorang muslim melainkan dipenuhi dengan tuntunan-tuntunan doa didalamnya, mulai dari ketika ia bangun tidur, makan dan minum, berpakaian, berinterkasi dengan manusia dan lain sebagainya sampai dengan ketika ia akan tidur kembali. Sehingga dapat 
dikatakan bahwa semua aktifitas dan ibadah yang dilakukan seorang muslim semuanya bermuara pada satu hakikat yaitu doa.

\section{Transedental}

Doa Sebagai Komunikasi

Doa dalam agama diposisikan sebagai bagian dari sarana untuk mendekatkan diri kepada Allah. ${ }^{34}$ Terkabulnya sebuah doa yang diajukan oleh manusia kepada Allah Swt adalah sesuatu yang sangat diharapkan dan membawa kebahagiaan. Namun banyak dari manusia yang berdoa dan kemudian merasa tidak mendapatkan jawaban atau mendapatkan apa yang diinginkannya dalam permintaan doanya. Salah satu penyebab dari hal ini adalah tidak tahunya manusia tentang hakikat dari doa yang ia lakukan.

Jika ditelae ah lebih dalam, sesungguhnya ada sesuatu yang istimewa yang terdapat dalam sebuah doa. Berdoa sesungguhnya, bukanlah hanya sebuah ritual lisan yang diikuti dengan gumaman dan dengan gerak-geriknya mulut ketika melakukannya.setiap kata-kata yangterlontar dari doa menjadi bernilai karena diikuti dengan penghayatan danperenungan. Sesungguhnya, berdoa tanpa memahami arti dan maksud dari apayang dibacanya sama saja dengan tidak berdoa. ${ }^{35}$

Hakikat sesungguhnya dari doa yang menjadi inti dari semua ibadah adalah adanya sebuah

\footnotetext{
34. Muhammad Abdul Qadir Alcaff, Doa Puncak Penyesalan \& Tobat,h.14

35 . Anis Masykur dan Jejen Musfah,

Doa Ajaran Ilahi, Kumpulan Doa dalam AlQurean beserta Tafsirnya (Jakarta: Noura Books, 2013), h. 4.
}

hubungan komunikasi yang terjadi antara manusia dengan Tuhannya. Dalam ilmu komunikasi, hubungan komunikasi yang terjadi antara manusia dengan Tuhannya inidisebut dengan komunikasi transendental ${ }^{36}$.

$$
\text { Dalam kajian ilmu }
$$

komunikasi, komunikasi transedental merupakan sesuatu yang menarik untuk dikaji.Menarik karena komunikasi yang terjadi didalam komunikasi transendental mempunyai sisi dan dimensi komunikasi yang kompleks.Dikatakan kompleks karena didalam komunikasi transedental juga terdapat sisi komunikasi intrapersonal dan juga interpersonal serta aspek komunikasi lainnya yang dapat dikaji dari kajian ilmu komunikasi.

Dari sisi intrapersonal, doa dapat dipahami sebagai sebuah aktifitas keagamaan dimana terjadi dialog intrapersonal yang secara sadar dilakukan seseorang dalam dirinya sendiri, di mana disaat yang sama ia juga ikut merasakan secara intuitif bahwa ia sedang datang dan berhubungan dengan Tuhannya sebagai tanda kepatuhan atau tanda komitmen makhluk kepada Tuhannya $^{37}$.

Sedangkan dari sisi komunikasi interpersonal dapat ditarik keterkaitan bahwa doa adalah sebuah dialog komunikasi yang dilakukan seseorang secara sadar

\footnotetext{
${ }^{36}$. Deddy Mulyana, Nuansa-Nuansa Komunikasi; Meneropong Politik Dan Budaya Komunikasi Masyarakat Kontemporer (Remaja Rosdakarya, Bandung: 1999) h. 49 37 .Rijardus A.Van Koiij, dkk., Menguak Fakta Menata Karya Nyata (Jakarta: Gunung Mulia, 2008), h.101
} 
sebagai pribadi dengan pribadi lainnya diluar dirinya, yaitu dirinya sendiri dengan Tuhannya.Komunikasi interpersonal ini terjadi karena adanya suatu pesan yang ingin disampaikan atau karena adanya suatu keinginan yang yang diinginkan oleh komunikator terhadap komunikannya. ${ }^{38}$

$$
\text { Dalam Ajaran Islam, }
$$

hubungan manusia dengan Tuhannya dapat dibangun melalui amalan ibadah yang di syariat Allah Swt kepada hambanya. Hakikat semua ibadah yang disyariatkan bagi seorang muslim seperti shalat, puasa, zakat, dan lain sebagainya itu, sesungguhnya bukan hanya sebagai sebuah syariat yang menunjukkan bukti kebenaran kehambaan seseorang kepada Allah Swt saja, akan tetapi hakikatnya adalah sebagai sarana, jalan atau cara yang Allah Swt berikan kepada manusia untuk dapat berkomunikasi dan membangun hubungan serta terhubung dengan diriNya(QS.Thaha:14). ${ }^{39}$

Melalui doa, seorang muslim dapat melakukan komunikasi dengan Allah Swt tanpa hijab atau penghalang yang menghalangi. Saat seorang muslim beribadah dan berdoa dengan penuh kekhusyukan, maka akan terjadi proses transformasi diri secara substansial dalam diri dan jiwa manusia yang akan membuatnya secara intuitif merasakan vibrasi atau getaran keterhubungan dirinya dengan Allah Swt(QS.An.Anfal:2). ${ }^{40}$

\footnotetext{
${ }^{38}$. Daryanto, Ilmu Komunikasi, Bandung, Satu Nusa,2013,h.35

39 . Departemen Agama RI, Syaamil

Qurean The Miracle,h.623

${ }^{40}$. Ibid.h.351
}

\section{Komunikasi Transedental Dalam Prespektif Komunikasi Islam}

Vibrasi keterhubungan yang terjadi antara diri manusia dengan Tuhannya dalam doa, sesungguhnya dapat dikaji dan ditarik keterkaitannya dengan kajian ilmu komunikasi. Jika dikaji dari sudut pandang komunikasi Islam, komunikasi transedental sesungguhnya mempunyai aspek yang sama dengan konsep-konsep dasar yang ada dalam komunikasi.
Harol
$\mathrm{D}$
Lasswel

mendefinisikan bahwa komunikasi adalah sebuah kegiatan yang sedikitnya melibatkan lima unsur komunikasi yaitu siapa mengatakan apa melalui chanel apa, kepada siapa dan memiliki efek apa atau berdampak apa. ${ }^{41}$

David

K.Berlo mendefinisikan komunikasi dengan sebuah teori dan model komunikasinya yang terkenal yaitu SMCR (Source, Message, Channel, Receiver) yang menjelaskan bahwa komunikasi adalah sebuah proses dimana subjek atau sumber melakukan aktifitas pengiriman pesan yang dilakukan dengan menggunakan perantara atau chanel kepada penerima atau komunikan. ${ }^{42}$

Secara sederhana termonologi komunikasi dapat diartikan sebagai proses penyampaian pesan dari sumber atau yang disebut komunikator kepada objek yang menjadi penerima pesannya yang disebut komunikan, melalui sebuah media dan menghasilkan sebuah respon.

\footnotetext{
${ }^{41}$.Hafied Cangara, Pengantar Ilmu Komunikasi.h21

${ }^{42}$ Ibid.h. 26
} 
Selain itu, dalam konsep dasar komunikasi secara lebih detail dapat dilihat pula bahwa komunikasi adalah halyang dinamis dimana didalam komunikasi terdapat bagianbagian proses dasar dan saling terhubung satu dengan yang lainnya. Dalam sebuah proses komunikasi terdapat komunikator sebagai sumber, adanya pengiriman sandi atau kode encoding, terdapat pesan, penerimaan kode sandi dan akhirnya menghasilkan respon timbal balik antara komunikator dengan komunikan. Hubungan encoding dan decoding ini adalah hubungan antara sumber dan penerima secara simultan dan saling mempengaruhi satu dengan yang lainnya. ${ }^{43}$

Dalam prespektif komunikasi Islam, Doa merupakan salah satu sarana yang Allah Swt berikan tuntunan dan panduannya kepada seorang muslim untuk dapatmembangun hubungan, dan terhubung dengan Allah Swt. Doa ini pula yang menjadi bagian yang tidak terpisahkan dalam kehidupan seorang muslim, karena segala aktifitas ibadah yang ia lakukan sesungguhnya bermuara pada satu inti yaitu doa.

Doa dalam ajaran Islam, sesungguhnya bukan hanya sebagai sebuah ritual keagamaan yang diikuti dengan tata tertib yang telah diajarkan Nabi dan berisi permintaan serta permohonanseorang hamba dengan Tuhannya saja, akan tetapi doa adalah sebuah sarana komunikasi antara manusia dengan Tuhannya yaitu Allah Swt, yang dilakukan manusia untuk memperoleh apa yang ia inginkan termasuk ketenangan

43. Ibid, h. 49 batin dan jiwanya dalam kehidupan yang ia jalani (Ar-Ra'edu:28). ${ }^{44}$

Sebagai

peristiwa berkomunikasinya manusia dengan Allah Swt, dalam komunikasi transedental juga terdapat aspek dan unsur komunikasi seperti komunikasi lain pada umumnya. Di dalamnya tedapat komunikator yang menjadi sumber inti dari terjadinya peristiwa komunikasi, pesan, dan penerima pesan yang menjadi objek dari sasaran pesan yang dikirim oleh komunikator, serta respon atau feedback sebagai bagian dari dampak pesan yang diberikan komunikator kepada penerima pesan, yang dapat berupa hubungan timbal balik, maupun tercapainya tujuan yang diinginkan komuikator terhadap komunikan yang menerima pesannya.

Dalam prespektif ajaran Islam, adapun yang menjadi komunikator atau source yang merupakan sumber yang menjadi pengirim pesan dalam peristiwa doa ini adalah Allah Swt dan manusia.Hal ini karena dalam komunikasi, proses komunikasi bersifat sirkuler dan dinamis, dimana Allah Swt dan manusia dapat menjadi komunikator sekaligus juga komunikan yang secara bergantian saling bertukar peran. ${ }^{45} \mathrm{Di}$ mana dalam peristiwa doa ini, manusia mendatangi Allah Swt dengan sarana doa atau ibadah yang syariatnya telah Allah Swt berikan melalui Al-qurean dan tuntunan langsung dari Nabi Muhammad Saw melalui hadisthadistnya, dan kemudian berinteraksi serta berkomunikasi denganNya.

\footnotetext{
${ }^{44}$. Departemen Agama RI, Syaamil Quree an The Miracle.h.501

45 . Daryanto.Ilmu Komunikasi, h. 32
} 
Dalam doa, agar doa yang diajukannya terkabul dan diijabah oleh Allah Swt, manusia sebagai sumber yang mengirimkan pesan berupa permintaan dan permohonannya kepada Allah Swt, haruslah mampumeminimalisir atau bahkan menghilangkan segala unsur gangguan yang mungkin dapat menjadi penyebab terganggunya atau tidak sampainya sebuah doa yang ia sampaikan kepada Allah Swt.

Selain itu, dalam berdoa seseorang juga harus mengikutsertakan segala aturan yang telah ditentukan dalam ajaran Islam,termasuk juga mengikutserta hati dan perasaannya secara sungguhsungguh ketika berkomunikasi kepada Allah Swt. Hal ini seperti yang Allah Swt firmankan dalam Al-quran yang terdapat pada Surat Al-Baqarah Ayat 186 yang berbunyi :

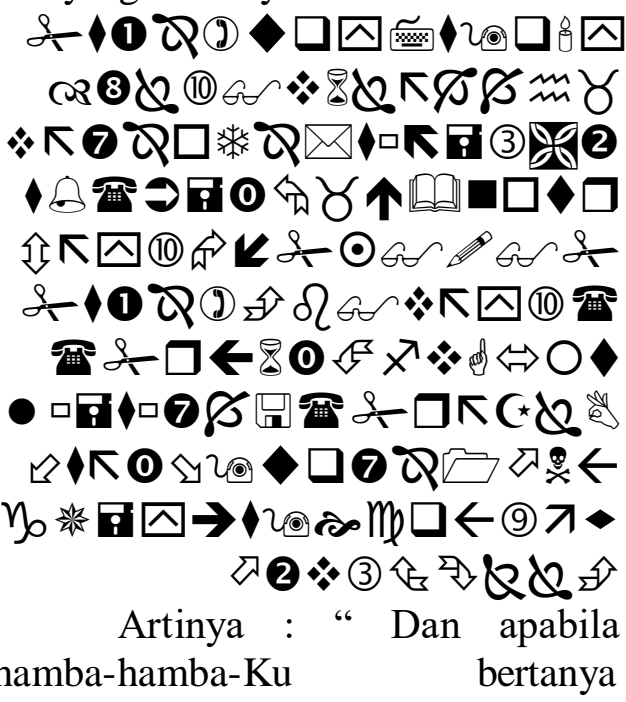

kepadamu tentang Aku, Maka (jawablah), bahwasanya aku adalah dekat. aku mengabulkan permohonan orang yang berdoa apabila ia memohon kepada-Ku, Maka hendaklah mereka itu memenuhi (segala perintah-Ku) dan hendaklah mereka beriman kepada-Ku, agar mereka selalu berada dalam kebenaran"(Al-Baqarah Ayat 186). ${ }^{46}$

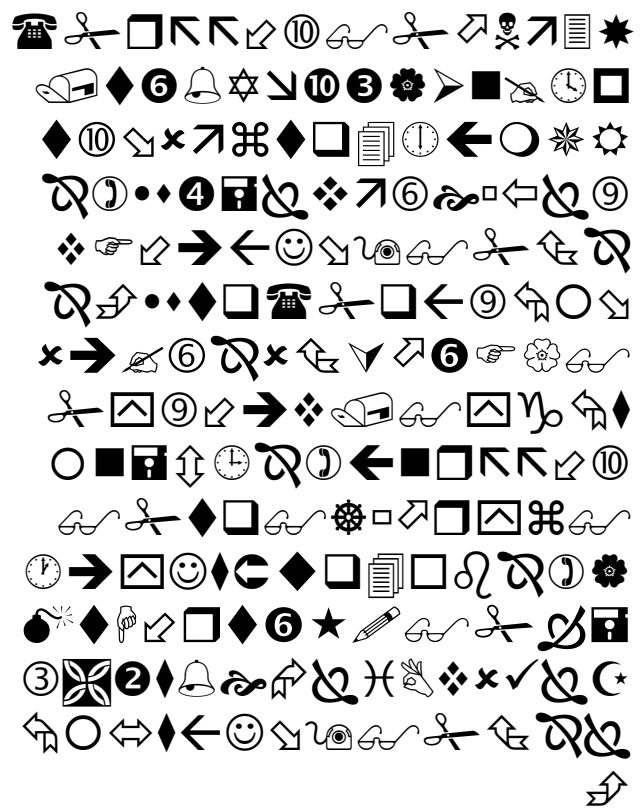

Artinya: "Berdoalah kepada Tuhanmu dengan berendah diri dan suara yang lembut. Sesungguhnya Allah tidak menyukai orang-orang yang melampaui batas. Dan janganlah kamu membuat kerusakan di muka bumi, sesudah (Allah) memperbaikinya danBerdoalah kepada-Nya dengan rasa takut (tidak akan diterima) dan harapan (akan dikabulkan). Sesungguhnya rahmat Allah Amat dekat kepada orangorang yang berbuat baik".

Dari dua ayat ini dapat dipahami bahwa, agar doa yang diajukannya terkabul dan diijabah oleh Allah Swt, seorang muslim sebagai sumber yang mengirimkan pesan berupa permintaan kepada Allah Swt, haruslah mengikutsertakan segala aturan yang telah ditentukan dalam ajaran Islam, termasuk juga mengikutserta hati dan jiwanya ketika berdoa kepada Allah Swt.

\footnotetext{
${ }^{46}$.Departemen Agama RI, Syaamil Qurean The Miracle.h.53
} 
Sedangkan dari sisi pesan, pesan komunikasi transedental yang terjadi dalam aktifitas doa atau ibadahadalah segala sesuatu yang disampaikan pengirimkepada penerima. ${ }^{47}$ Pesan dalam sebuah doa adalah segala permintaan dan permohonan yang diminta oleh seorang muslim kepada Allah Swt. Pesan tersebut dapat berisi permintaan, pertanyaan, memohon perlindungan, permohonan ampunan dan lain sebagainya. Hal ini seperti yang Allah Swt firmankan dalam Al-quran yang terdapat pada Surat Al-Muzammil Ayat 20 yang berbunyi :

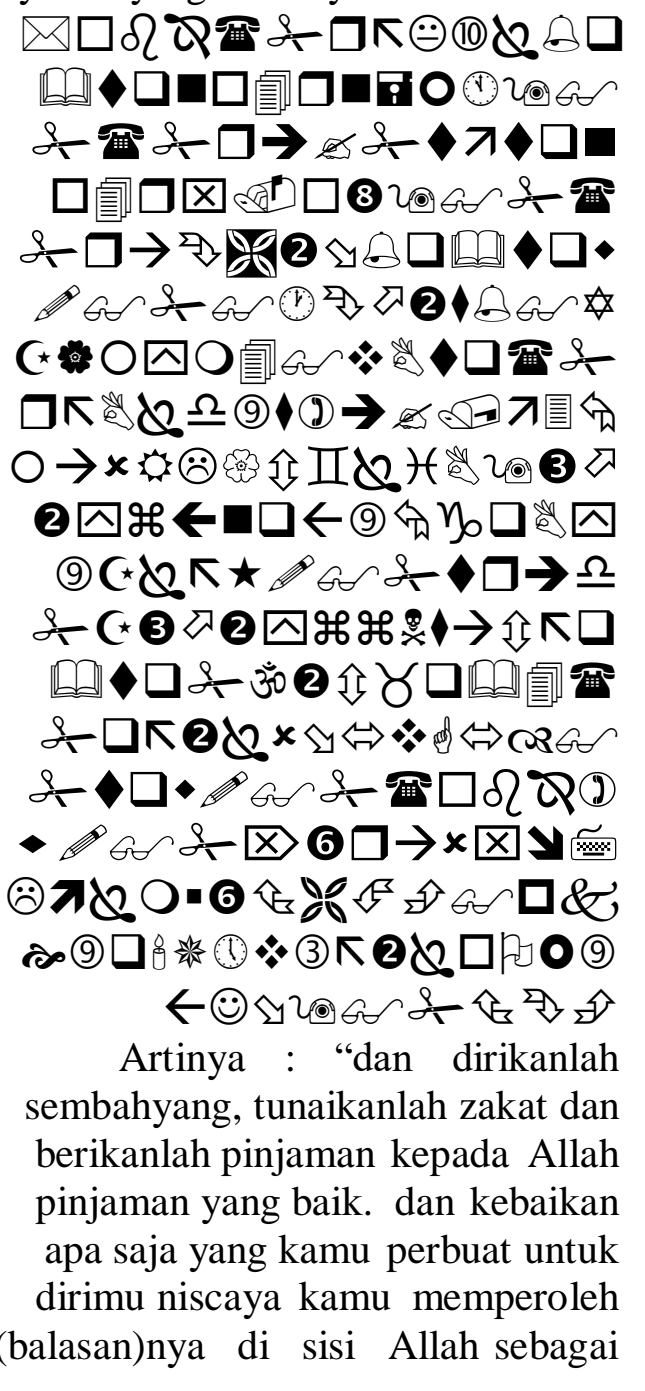

${ }^{47}$. Daryanto, Ilmu Komunikasi,h. 27
Balasan yang paling baik dan yang paling besar pahalanya. dan mohonlah ampunan kepada Allah; Sesungguhnya Allah Maha Pengampun lagi Maha Penyayang"(Al-Muzammil Ayat 20). ${ }^{48}$

Selain dari sisi komunikator dan pesan, dalam komunikasi transedental juga dapat dilihat terdapat saluran yang menjadi penghubung atau perantara dalam komunikasi yang terjadi antaraseorang hambadengan Tuhannya. Dalam aktifitas ini, ritual doa inilah yang menjadi media atau perantara yang menjadi sarana penghubung dan keterhubungan antara manusia dengan Tuhannya yaitu Allah Swt. Doa menjadi sebuah syariat yang Allah Swt berikan dan jadikan sebagaikepada manusia agar dapat membangun hubungan dan terhubung dengan diriNya yang Maha Agung.

Terakhir, seperti layaknya komunikasi lainnya yang juga terdapat komunikan respon, dan juga effek, didalam komunikasi transedental juga terdapat komunikan, respon dan jugaeffek yang menjadi bagian dalam proses komunikasi yang terjadi. Komunikan dalam doa yang disampaikan manusia ini adalah suatu Dzat yang disadari dan dipahami manusia sebagai sesuatu yang berada serta memiliki kemampuan diluar batas kemampuan dirinya sebagai manusia biasa, Dzat yang Maha besar yaitu Allah Swt.

Sedangkan responnya adalah segala sesuatu yang merupakan

\footnotetext{
${ }^{48}$.Departemen Agama RI, Syaamil Qur ${ }^{\text {ee }}$ an The Miracle.h.1145
} 
dampak dari komunikasi yang dilakukan seorang muslim kepada Allah Swt. Respon tersebut merupakan indikator terhubung atau tidaknya seorang muslim dengan Tuhannya dalam ibadah doa yang ia lakukan. Respon tersebut dapat berupa terwujudnya keinginan yang ia inginkan, terjawabnya pertanyaan yang ia ajukan, diampunkannya permohoan ampunan dan lain sebagainya yang diikuti dengan adanya effek berupa terjadinya perubahan diri kearah yang lebih baik, atau dapat pula dalam bentuk lainnya yang langsung dapat dipahami ataupun yang nanti pada akhirnya baru dipahami oleh manusia.

Effect adalah hasil akhir dari suatu proses komunikasi yang terjadi. Menurut Deddy Mulyana, keberhasilan komunikasi dengan Allah, sama dengan dengan keberhasilan komunikasi dengan sesama manusia. ${ }^{49}$ keberhasilan komunikasi transedental ini, juga tidak terlepas dari ketepatan seseorangdalam mempersepsi diri sendiri, siapakah kita, apa tujuan hidup kita di dunia,dan mau kemana kita setelah hidup ini. ${ }^{50}$

Seorang manusia yang semakin mengenaldirinya sendiri maka akan semakin dekat dengan Allah Swt.Sehingga jika dirinya telah dekat dan memahami hakikat berkomunikasi dengan Allah Swt, maka ia akan dengan mudah membangun hubungan dan keterhubungan dengan Allah Swt, sehingga tidak ada lagi resistor yang menjadi penghambat dan penghalang

\footnotetext{
${ }^{49}$.Deddy Mulyana, Nuansa-Nuansa Komunikasi; Meneropong Politik.h.49 ${ }^{50}$. Ibid. 52
}

antara dirinya dengan Allah Swt yang juga akan berimbas pada diterimanya segala amalan dan doa yang ia lakukan.

\section{Kesimpulan}

Dari paparan diatas, dapat disimpulkan bahwa pada hakikatnya doa yang dilakukan seseorang adalah sebuah sarana berkomunikasi antara dirinya dan Allah Swt. Doa menjadi inti dari semua ibadah yang yang dilakukan karena pada hakikatnya semua ibadah yang dilakukan seorang muslim adalah komunikasi antara dirinya dan Tuhan. Sehingga jika ini benarbenar diresapi dan dipahami, maka akan terjadilah komunikasi yang dekat antara manusia dengan Allah Swt. yang akan berefek pada sampai dan diterimanya doa yang ia ajukan.

\section{Daftar Pustaka}

Abd al-Qadir Ahmad Atha(1405 H/1985 M).Hadzâ Halâl wa Harâm. Beirut: Dar al-Kutub alIlmiyah.

Adil Abû Hafash Umar bin „Ali bin Hambali(1998).alLubâb fî̀ „Ulûm alKitâb, juz II, cet. I. Beirut: Dâr al„Ilmiyah.

Ahmad

Warson

Munawir(2002). Al-Munawir:

Kamus Arab-Indonesia. Surabaya : Pustaka Progresif.

Anis Masykur dan Jejen Musfah (2013).Doa Ajaran Ilahi, Kumpulan Doa dalam Al-Qur'an beserta Tafsirnya. Jakarta: Noura Books.

At-Tirmiż̄î, Jāmi' at-Tirmiż̀̄ “Kitāb ad-Da'awāt: Bāa Mā Jā'a fì 
Faḍl ad-Du'ā'. Riyāḍ: Bait al-Afkār ad-Daulyah, T.th.

Daryanto(2013).Ilmu

Komunikasi. Bandung : Satu Nusa.

Deddy Mulyana (1999).Nuansa-Nuansa Komunikasi; Meneropong Politik Dan Budaya Komunikasi Masyarakat Kontemporer.Bandung: Remaja Rosdakarya.

Djamaluddin Ancok Dan Fuad nashori Suruso (1994). Psikologi Islam : Solusi Islam Atasi ProblemProblem Psikologi.Yogyakarta : Pustaka Pelajar.

H. Ramayulis(2002).Psikologi Agama. Jakarta: kalam Mulia.

IqbaI Hasan(2008).Analisis Data Penelitian Dengan

Statistik.Jakarta:Bumi Aksara.

Kementerian Agama RI (2013). Hijaz The Practice. Bandung :Syaamil Qurean.

Komarudin Hidayat Dan Muhmmad Wahyuni Nafis (1995). Agama Masa Depan: Persepektif Filsafat Pernial. Jakarta : Paramadina.

Muhammad Natsir(1999). Metode Penelitian. Jakarta : Ghalia Indonesia.
M. Majma ae al-Lugah al„Arabiyah, Mư jam Alfầz al-Qureân al-Karîm (Kairo: Dâr al-Syurûq, t.th.)

Muhammad Abdul Qadir Alcaff (2008).Doa Puncak Penyesalan \&Tobat . Jakarta: Zahra.

$\mathrm{M}$. Quraish Shihab(2008).Wawasan al-Qur'an tentang Zikir dan Doa, cet. ke-3. Jakarta: Lentera Hati.

M.Quraish Shihab (1994). Tafsir Al-Amanah. Pustaka Kartini.

Nurcholis Majid (1995).Islam Agama Peradaban Membangun Makna dan Relevansinya Doktrin Islam dalam Sejarah.Jakarta : Paramdina.

Robert H. Thouless(2000). Pengantar Psikologi Doa, Cet. Ketiga. Jakarta: Raja Grafindo Persada.

Rudolf Otto (1923).The Idea of the holy.London : Oxpord University Press.

Rusmin Tumanggor (2014).Ilmu Jiwa Agama.Jakarta :Prenadamedia group. 